\title{
Associations between Smoking, Intrauterine Device Uptake, and Ectopic Pregnancy: A Meta Analysis
}

\author{
Ridha Rossela Yanuari'), Eti Poncorini Pamungkasari²), Vitri Widyaningsih²) \\ 1)Masters Program in Public Health, Universitas Sebelas Maret \\ 2)Faculty of Medicine, Universitas Sebelas Maret
}

Background: Ectopic pregnancy is an important cause of maternal morbidity and mortality, estimated to occur in approximately $1-2 \%$ of pregnancies worldwide. Smoking and history of using intrauterine devices are risk factors for ectopic pregnancy. This study aims to estimate the magnitude of the relationship between smoking and a history of using intrauterine devices on the incidence of ectopic pregnancy based on a number of previous primary studies.

Subjects and Method: This study is a systematic review and meta-analysis. The articles used in this study were obtained from several databases, including: PubMed, Google Scholar, and Science Direct which were published from 2000-2020. The inclusion criteria used are full text articles with Case Control design. The keywords used to search for articles were as follows: smoking AND "ectopic pregnancy" AND multivariate; "use of intrauterine device" AND "ectopic pregnancy" AND multivariate; smoking OR cigarette AND "use of intrauterine device" AND "ectopic pregnancy" OR "tubal pregnancy" AND multivariate. Articles were collected using PRISMA flow diagrams and analyzed using the Review Manager 5.3.

Results: A meta-analysis of 7 articles showed that women of reproductive age who smoked had a 2.20 times risk of ectopic pregnancy compared to women of reproductive age who did not smoke $(\mathrm{aOR}=2.20 ; 95 \% \mathrm{CI}=1.45$ to $3.34 ; \mathrm{p}=0.002)$. A meta-analysis of 9 articles showed that women of reproductive age with a history of using intrauterine devices had a 2.28 times risk of ectopic pregnancy compared to women of reproductive age who did not use intrauterine devices (aOR= 2.28; $95 \% \mathrm{CI}=1.74$ to $2.98 ; \mathrm{p}<0.001)$.

Conclusion: Smoking and a history of using intrauterine devices increase the risk of ectopic pregnancy.

Keywords: smoking, intrauterine contraceptives, ectopic pregnancy, meta-analysis

\section{Correspondence:}

Ridha Rossela Yanuari. Masters Program in Public Health, Universitas Sebelas Maret. Jl. Ir. Sutami 36A, Surakarta 57126, Central Java. Email: ridharosselayanuari@gmail.com. Mobile: 085747311182

\section{Cite this as:}

Yanuari RR, Pamungkasari EP, Widyaningsih V (2021). Associations between Smoking, Intrauterine Device Uptake, and Ectopic Pregnancy: A Meta Analysis. 06(03): 388-399. https://doi.org/10.26911/thejmch.2021.06.04.01 Attribution-NonCommercial-ShareAlike 4.0 International License.

\section{BACKGROUND}

Ectopic pregnancy is an important cause of maternal morbidity and mortality, estimated to occur in approximately $1-2 \%$ of pregnancies worldwide (Orazulike and Konje, 2013). An ectopic pregnancy is caused by blockage of the fallopian tube or reduction of tubal perspiration that prevents the fertilized ovum from reaching the uterus (Lewis et al., 2017). Ectopic pregnancy poses a significant threat to 
women of reproductive age (Barash et al., 2014).

The main symptoms of an ectopic pregnancy include abdominal or pelvic pain, amenorrhea or missed periods, and vaginal bleeding with or without clotting. Other symptoms include gastrointestinal symptoms, dizziness, fainting, shoulder tip pain, urinary symptoms and rectal pressure or pain during bowel movements (Orazulike and Konje, 2013). The results of the study stated that as many as $81.9 \%$ and $57.8 \%$ of women with ectopic pregnancies experienced moderate or heavy bleeding and the presence of pain was significantly and positively related to the presence of an ectopic pregnancy (Barnhart et al., in Moini et al., 2014). Serial measurement of serum human chorionic gonadotropin (hCG) combined with transvaginal ultrasound is used to diagnose ectopic pregnancy (Demirdag et al., 2016).

Studies report that ectopic pregnancy is the leading cause of maternal death in Africa accounting for $0.5 \%-2.3 \%$ of all deaths. In Southeast Asia the incidence of ectopic pregnancy is $1.48 \%$. The highest incidence of ectopic pregnancy is reported from African countries i.e. 0.5\%-2.3\% of live births, the incidence of ectopic pregnancy in Pakistan is $0.5 \%-1.5 \%$, while the lowest incidence is reported from Asia and the Middle East. ie $0.4 \%-0.6 \%$ of live births (Ain et al., 2019). Several risk factors are suspected to be the cause of ectopic pregnancy, including a history of pelvic inflamematory disease, history of tubal surgery, history of ectopic pregnancy, tubal blockage, maternal age, smoking, history of using intrauterine devices, history of abortion, history of infertility (Moini et al. , 2014).

Smoking has been shown to be an increased risk factor for ectopic pregnancy. The increased risk ranges from 1.6 to 3.5 times compared to non-smokers (Patil,
2012). Some of the mechanisms of this relationship may be delayed ovulation, altered tubal and uterine motility and microenvironment, or altered immunity (Sivalingam et al., 2011). Method of contraception only after IUD use, there was a 4-5 times increased risk of subsequent ectopic pregnancy (OR 4.39, 95\% CI= 1.78 to 10.81). Although the exact mechanism of implantation occurring outside the uterus is not well understood, it is thought that IUD-induced inflammation may cause endosalpinx decilation and subsequently delay egg transport, leading to ectopic pregnancy (Moini et al., 2014).

Various studies have been conducted to examine the relationship between smoking and a history of using intrauterine devices on the incidence of ectopic pregnancy, but the results of the study have not shown consistent results. Further analysis is needed to arrive at a convincing conclusion. Therefore, researchers are interested in examining the relationship between smoking and history of using intrauterine devices on the incidence of ectopic pregnancy. The researcher used a systematic review approach to clearly identify the relationship between smoking and history of using intrauterine devices on the incidence of ectopic pregnancy.

\section{SUBJECTS AND METHOD}

\section{Study Design}

The study design used in this study was a systematic review and meta-analysis, using the PRISMA diagram flow. Article searches were conducted using journal databases including: PubMed, Google Scholar and Science Direct. The keywords used are smoking AND "ectopic pregnancy" AND multivariate; "use of intrauterine device" AND "ectopic pregnancy" AND multivariate; smoking OR cigarette AND "use of intrauterine device" AND "ectopic preg- 
Yanuari et al./ Smoking, Intrauterine Device Uptake, and Ectopic Pregnancy

nancy" OR "tubal pregnancy" AND multivariate.

\section{Inclusion Criteria}

In this study, the inclusion criteria were full text articles using an observational case control study design, articles in English, the analysis used was multivariate with adjusted odds ratio. The study subjects are women of reproductive age, the intervention is smoking and a history of using intrauterine devices.

\section{Exclusion Criteria}

Exclusion criteria in this study include articles published before 2000 and languages other than English.

\section{Operational Definition of Variables}

In formulating research problems here using PICO. Population is women of reproductive age. The intervention was smoking and a history of using intrauterine devices, with a comparison of not smoking and not using intrauterine devices and the outcome was ectopic pregnancy.

Smoking is an activity of burning tobacco cigarettes which involves the process of entering smoke into the body by sucking it.

Intrauterine contraception is a device or object that is inserted into the uterus which is very effective, reversible, long- term, and can be used by all women of reproductive age.

An ectopic pregnancy is a pregnancy that occurs outside the uterus.

\section{Instrument}

An assessment of the quality of research articles is carried out using the Critical Appraisal Checklist for case control (CEBMa, 2014).

\section{Data Analysis}

The Review Manager application (RevMan 5.3) was used in analyzing the data in this study. The results of data analysis are in the form of effect size values and study heterogeneity which later the results of the analyzed data are interpreted in the form of forest plots and funnel plots.

\section{RESULTS}

Research from primary studies related to the relationship of smoking and history of using intrauterine devices to the incidence of ectopic pregnancy consisted of 12 studies originating from 7 studies from the Asia, 2 studies from the Africa, 3 studies from the Europe.

The article search was carried out using a database based on the PRISMA flow diagram which can be seen in Figure 1.

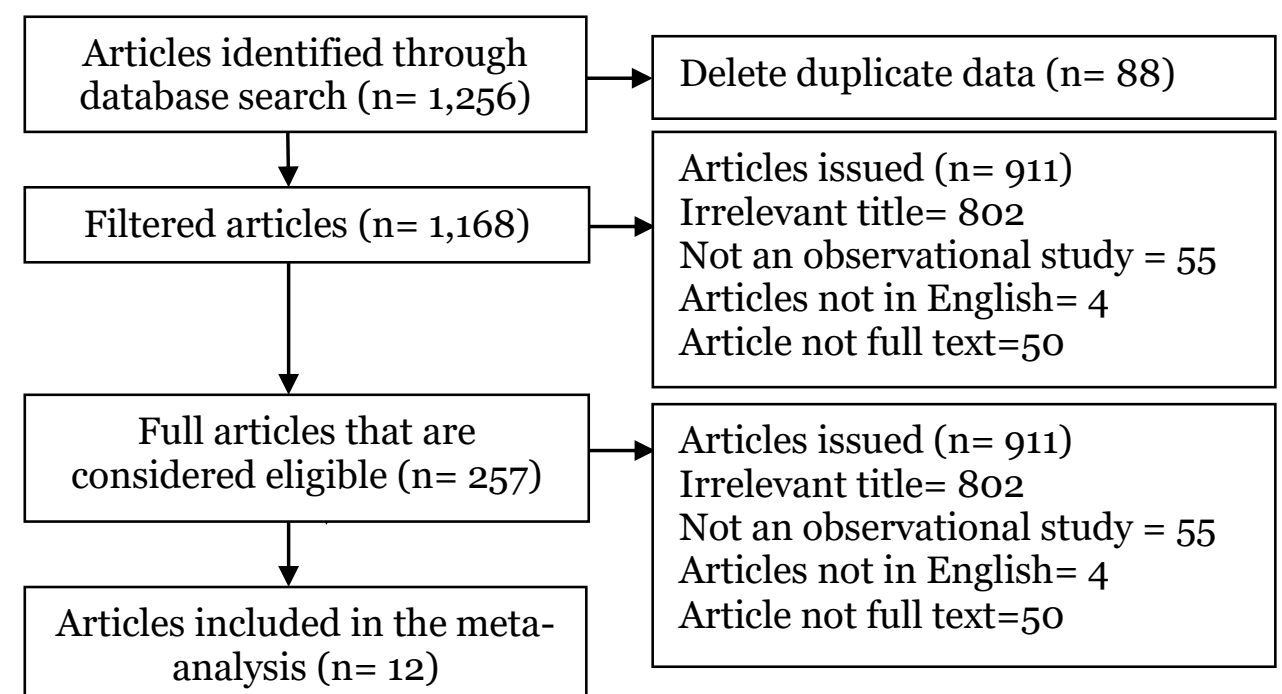

Figure 1. PRISMA flow diagram 
Yanuari et al./ Smoking, Intrauterine Device Uptake, and Ectopic Pregnancy

Furthermore, the researchers conducted an assessment of the quality of the articles (Tables 1 and 2). While table 3 shows that there are 7 case control study articles with the independent variable smoking and table 4 shows there are 9 case control study

Table 1. Assessment of Research Quality on the Relationship of Smoking to Ectopic Pregnancy

\begin{tabular}{|c|c|c|c|c|c|c|c|c|c|c|c|c|c|}
\hline \multirow{2}{*}{ Primary Study } & \multicolumn{12}{|c|}{ Criteria } & \multirow{2}{*}{ Total } \\
\hline & $\mathbf{1}$ & 2 & $\mathbf{3}$ & 4 & 5 & 6 & 7 & 8 & 9 & 10 & $\mathbf{1 1}$ & 12 & \\
\hline Bouyeret al (2000) & 1 & 1 & 1 & 1 & 1 & $\mathrm{O}$ & $\mathrm{O}$ & 1 & 1 & 1 & 1 & 1 & 10 \\
\hline Bouyeret al (2003) & 1 & 1 & 1 & 1 & 1 & 1 & 1 & 1 & 1 & 1 & 1 & 1 & 12 \\
\hline Karaeret al (2006) & 1 & 1 & 1 & 1 & 1 & 1 & 1 & 1 & 1 & 1 & 1 & 1 & 12 \\
\hline Karaer et al (2013) & 1 & 1 & 1 & 1 & 1 & O & O & 1 & 1 & 1 & 1 & 1 & 10 \\
\hline Taranet al (2015) & 1 & 1 & 1 & 1 & 1 & 1 & 1 & 1 & 1 & 1 & 1 & 1 & 12 \\
\hline Kashanianet al. (2016) & 1 & 1 & 1 & 1 & 1 & 1 & 1 & 1 & 1 & 1 & 1 & 1 & 12 \\
\hline Mindjahet al (2018) & 1 & 1 & 1 & 1 & 1 & 1 & 1 & 1 & 1 & 1 & 1 & 1 & 12 \\
\hline
\end{tabular}

Note:

Answer $1=$ Yes

Answer $0=$ No

Table 2. Assessment of the Quality of Research on the Relationship of History of Using Contraceptive Devices in the Uterus to the Incident of Ectopic Pregnancy

\begin{tabular}{|c|c|c|c|c|c|c|c|c|c|c|c|c|c|}
\hline \multirow{2}{*}{ Primary Study } & \multicolumn{12}{|c|}{ Criteria } & \multirow{2}{*}{ Total } \\
\hline & 1 & 2 & 3 & 4 & 5 & 6 & 7 & 8 & 9 & 10 & 11 & 12 & \\
\hline Bouyeret al (2000) & 1 & 1 & 1 & 1 & 1 & $\mathrm{O}$ & $\mathrm{O}$ & 1 & 1 & 1 & 1 & 1 & 10 \\
\hline Bouyeret al (2003) & 1 & 1 & 1 & 1 & 1 & 1 & 1 & 1 & 1 & 1 & 1 & 1 & 12 \\
\hline Anorluet al (2005) & 1 & 1 & 1 & 1 & 1 & 1 & 1 & 1 & 1 & 1 & 1 & 1 & 12 \\
\hline Karaer et al (2006) & 1 & 1 & 1 & 1 & 1 & 1 & 1 & 1 & 1 & 1 & 1 & 1 & 12 \\
\hline Parashi et al(2014) & 1 & 1 & 1 & 1 & 1 & 1 & 1 & 1 & 1 & 1 & 1 & 1 & 12 \\
\hline Li etal (2014) & 1 & 1 & 1 & 1 & 1 & 1 & 1 & 1 & 1 & 1 & 1 & 1 & 12 \\
\hline Liet al (2015) & 1 & 1 & 1 & 1 & 1 & 1 & 1 & 1 & 1 & 1 & 1 & 1 & 12 \\
\hline Zhanget al (2015) & 1 & 1 & 1 & 1 & 1 & 1 & $\mathrm{O}$ & 1 & 1 & 1 & 1 & 1 & 11 \\
\hline Kashanianet al (2016) & 1 & 1 & 1 & 1 & 1 & 1 & 1 & 1 & 1 & 1 & 1 & 1 & 12 \\
\hline
\end{tabular}

Note:

Answer $1=$ yes

Answer $0=$ no

The study quality assessment was carried out using the Critical Appraisal Checklist for Case control (CEBMa, 2014). The 12 questions used were as follows:

a. Does this objective clearly address the problem/focus of the research problem?

b. Is the case control research method suitable to answer the research question?

c. Are the cases representative of the designated population? articles with the independent variable being a history of using intrauterine devices. The results show that smoking and a history of using intrauterine devices increase the risk of ectopic pregnancy. 
Yanuari et al./ Smoking, Intrauterine Device Uptake, and Ectopic Pregnancy

h. Was the magnitude of the exposure effect assessed?

i. Was a confidence interval given for the main outcome? j. Are the results applicable to the designated population?

$\mathrm{k}$. Are the results of this study consistent with other available evidence?

Table 3. Description of the primary study of the relationship between smoking and the incidence of ectopic pregnancy

\begin{tabular}{|c|c|c|c|c|c|c|c|}
\hline $\begin{array}{c}\text { Author } \\
\text { (Year) }\end{array}$ & $\begin{array}{c}\text { Country } \\
\text { (Continent) }\end{array}$ & $\begin{array}{c}\text { Study } \\
\text { Design }\end{array}$ & Sample & $\mathbf{P}$ & $\mathbf{I}$ & $\mathbf{C}$ & $\mathbf{O}$ \\
\hline $\begin{array}{l}\text { Bouyeret al } \\
(2000)\end{array}$ & $\begin{array}{l}\text { Prancis } \\
\text { (Eropa) }\end{array}$ & $\begin{array}{l}\text { Case } \\
\text { Control }\end{array}$ & $\begin{array}{c}\text { Case: } 243 \\
\text { Control: } \\
140\end{array}$ & $\begin{array}{l}\text { Women of } \\
\text { reproductive } \\
\text { age }\end{array}$ & Smoking & $\begin{array}{l}\text { No } \\
\text { Smoking }\end{array}$ & $\begin{array}{l}\text { Ectopic } \\
\text { pregnancy }\end{array}$ \\
\hline $\begin{array}{l}\text { Bouyeret al } \\
(2003)\end{array}$ & $\begin{array}{l}\text { Prancis } \\
\text { (Eropa) }\end{array}$ & $\begin{array}{l}\text { Case } \\
\text { Control }\end{array}$ & $\begin{array}{c}\text { Case: } 803 \\
\text { Control: } \\
1683\end{array}$ & $\begin{array}{l}\text { Women of } \\
\text { reproductive } \\
\text { age }\end{array}$ & Smoking & $\begin{array}{l}\text { No } \\
\text { Smoking }\end{array}$ & $\begin{array}{l}\text { Ectopic } \\
\text { pregnancy }\end{array}$ \\
\hline $\begin{array}{l}\text { Karaeret al } \\
(2006)\end{array}$ & $\begin{array}{l}\text { Turki } \\
\text { (Asia) }\end{array}$ & $\begin{array}{l}\text { Case } \\
\text { Control }\end{array}$ & $\begin{array}{c}\text { Case: } 225 \\
\text { Control: } \\
375\end{array}$ & $\begin{array}{l}\text { Women of } \\
\text { reproductive } \\
\text { age }\end{array}$ & Smoking & $\begin{array}{l}\text { No } \\
\text { Smoking }\end{array}$ & $\begin{array}{l}\text { Ectopic } \\
\text { pregnancy }\end{array}$ \\
\hline $\begin{array}{l}\text { Karaer } \\
(2013)\end{array}$ & $\begin{array}{l}\text { Turki } \\
\text { (Asia) }\end{array}$ & $\begin{array}{l}\text { Case } \\
\text { Control }\end{array}$ & $\begin{array}{c}\text { Case: } 125 \\
\text { Control: } \\
125\end{array}$ & $\begin{array}{l}\text { Women of } \\
\text { reproductive } \\
\text { age }\end{array}$ & Smoking & $\begin{array}{l}\text { No } \\
\text { Smoking }\end{array}$ & $\begin{array}{l}\text { Ectopic } \\
\text { pregnancy }\end{array}$ \\
\hline $\begin{array}{l}\text { Taranet al } \\
(2015)\end{array}$ & $\begin{array}{l}\text { Jerman } \\
\text { (Eropa) }\end{array}$ & $\begin{array}{l}\text { Case } \\
\text { Control }\end{array}$ & $\begin{array}{c}\text { Case: } 225 \\
\text { Control: } \\
350\end{array}$ & $\begin{array}{l}\text { Women of } \\
\text { reproductive } \\
\text { age }\end{array}$ & Smoking & $\begin{array}{l}\text { No } \\
\text { Smoking }\end{array}$ & $\begin{array}{l}\text { Ectopic } \\
\text { pregnancy }\end{array}$ \\
\hline $\begin{array}{l}\text { Kashanian et } \\
\text { al (2016) }\end{array}$ & $\begin{array}{l}\text { Iran } \\
\text { (Asia) }\end{array}$ & $\begin{array}{l}\text { Case } \\
\text { Control }\end{array}$ & $\begin{array}{c}\text { Case: } 308 \\
\text { Control: } \\
616\end{array}$ & $\begin{array}{l}\text { Women of } \\
\text { reproductive } \\
\text { age }\end{array}$ & Smoking & $\begin{array}{l}\text { No } \\
\text { Smoking }\end{array}$ & $\begin{array}{l}\text { Ectopic } \\
\text { pregnancy }\end{array}$ \\
\hline $\begin{array}{l}\text { Mindjah } \\
\text { (2018) }\end{array}$ & $\begin{array}{l}\text { Kamerun } \\
\text { (Afrika) }\end{array}$ & $\begin{array}{l}\text { Case } \\
\text { Control }\end{array}$ & $\begin{array}{c}\text { Case: } 88 \\
\text { Control: } \\
176\end{array}$ & $\begin{array}{l}\text { Women of } \\
\text { reproductive } \\
\text { age }\end{array}$ & Smoking & $\begin{array}{l}\text { No } \\
\text { Smoking }\end{array}$ & $\begin{array}{l}\text { Ectopic } \\
\text { pregnancy }\end{array}$ \\
\hline
\end{tabular}

Table 4. Description of the primary study of the relationship between history of using intrauterine devices and the incidence of ectopic pregnancy

\begin{tabular}{|c|c|c|c|c|c|c|c|}
\hline $\begin{array}{l}\text { Author } \\
\text { (Year) }\end{array}$ & Country & $\begin{array}{c}\text { Study } \\
\text { Design }\end{array}$ & Sample & $\mathbf{P}$ & $\mathbf{I}$ & $\mathbf{C}$ & $\mathbf{O}$ \\
\hline & & $\begin{array}{l}\text { Case } \\
\text { Control }\end{array}$ & & $\begin{array}{l}\text { Women of } \\
\text { reproductive age }\end{array}$ & $\begin{array}{l}\text { History } \\
\text { using IUD }\end{array}$ & & \\
\hline & & se & To & of & IUD & & \\
\hline et & & ase & c & $\begin{array}{l}\text { of } \\
\text { ctive }\end{array}$ & & & \\
\hline Kar: & & se & & of & & & \\
\hline & & & & & & & \\
\hline & $\begin{array}{l}\text { Cina } \\
\text { (Asia) }\end{array}$ & ase & & of & & & \\
\hline & & & & of & & & $\begin{array}{l}\text { Ectopic } \\
\text { pregnancy }\end{array}$ \\
\hline $\begin{array}{l}\text { Zhang et al } \\
\text { (2015) }\end{array}$ & $\begin{array}{l}\text { Cina } \\
\text { (Asia) }\end{array}$ & $\begin{array}{l}\text { Case } \\
\text { Control }\end{array}$ & $\begin{array}{l}\text { Case: } 2411 \\
\text { Control: } 2419\end{array}$ & Women of & $\begin{array}{l}\text { History } \\
\text { using IUD }\end{array}$ & & $\begin{array}{l}\text { Ectopic } \\
\text { pregnancy }\end{array}$ \\
\hline $\begin{array}{l}\text { Kashanian } \\
\text { et al (2016) }\end{array}$ & $\begin{array}{l}\text { Iran } \\
\text { (Asia) }\end{array}$ & $\begin{array}{l}\text { Case } \\
\text { Control }\end{array}$ & $\begin{array}{l}\text { Case: } 308 \\
\text { Control: } 616\end{array}$ & $\begin{array}{l}\text { Women of } \\
\text { reproductive age }\end{array}$ & $\begin{array}{l}\text { History } \\
\text { using IUD }\end{array}$ & $\begin{array}{l}\text { Not using } \\
\text { an IUD }\end{array}$ & $\begin{array}{l}\text { Ectopic } \\
\text { pregnancy }\end{array}$ \\
\hline
\end{tabular}


Yanuari et al./ Smoking, Intrauterine Device Uptake, and Ectopic Pregnancy

1. The relationship between smoking and the incidence of ectopic pregnancy

\section{a. Forest plot}

Based on the results of the analysis in Figure 2, it can be seen that 7 articles reported that smoking increased the incidence of ectopic pregnancy. Based on the analysis, there was high heterogeneity between trials $\left(I^{2}=78 \% ; p=0.002\right)$ so the Random Effect Model (REM) was used. Random Effect Model (REM) is used if $\mathrm{I}^{2}$ $>50 \%$. Women of reproductive age who smoked had 2.20 times the risk of having an ectopic pregnancy compared to women of reproductive age who did not smoke $(\mathrm{aOR}=2.20 ; 95 \% \mathrm{CI}=1.45$ to $3.34 ; \mathrm{p}=$ $0.002)$.

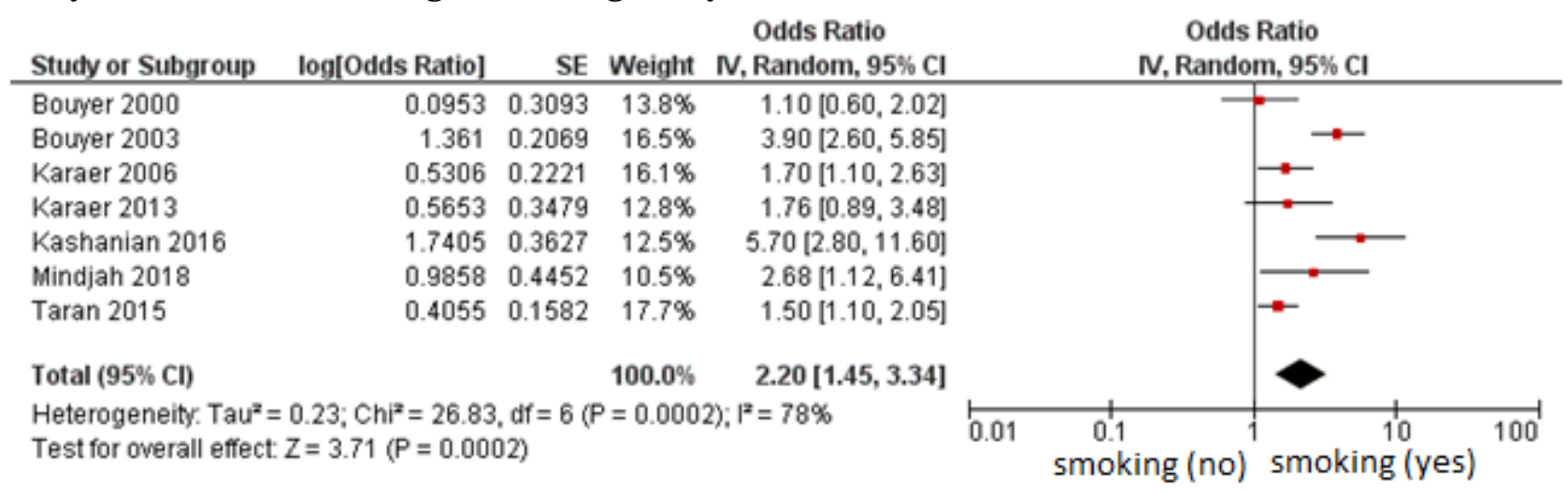

Figure 2. Forest plot of the relationship between smoking and the incidence of ectopic pregnancy

\section{b. Funnel plot}

Figure 3 shows the absence of publication bias indicated by the symmetrical distribution of the right and left plots where there are 3 plots on the right and 4 plots on

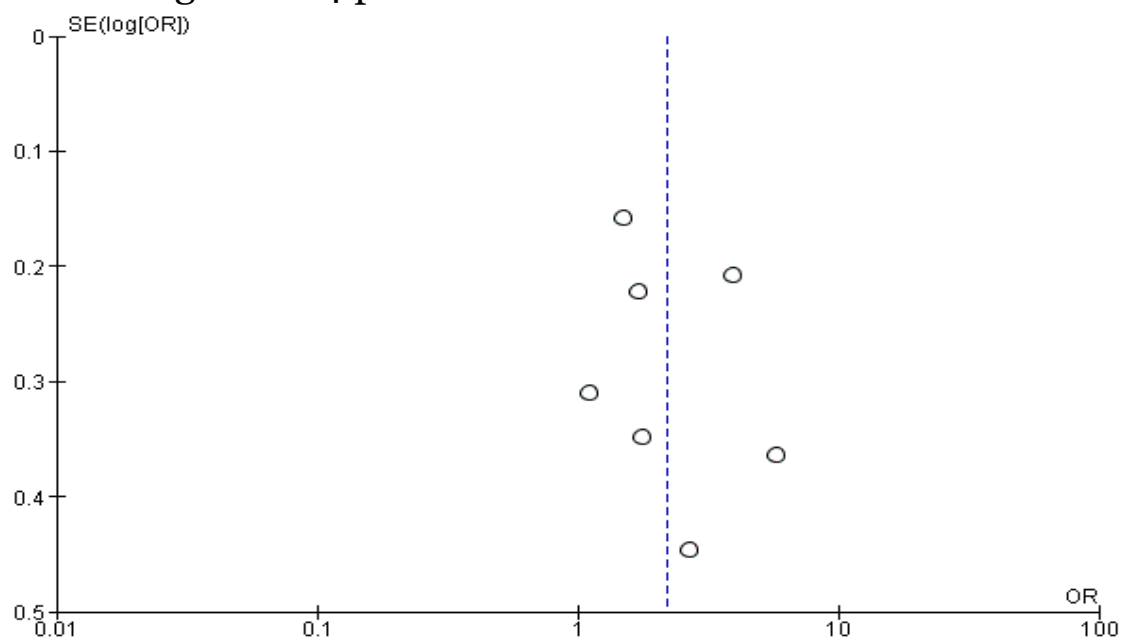

Figure 3. Forest plot of the relationship between smoking and the incidence of ectopic pregnancy

\section{a. Forest plot}

Based on the results of the analysis in the left. The plot on the left of the graph has a standard error of 0.1 and 0.4 between, while the plot on the right of the graph has a standard error of between 0.2 and 0.5 . 
intrauterine devices increased the incidence of ectopic pregnancy. Based on the analysis, there was a high heterogeneity between trials ( $2=70 \% ; \mathrm{p}=0.009$ ) so the Random Effect Model (REM) was used. Random Effect Model (REM) is used if I2 > 50\%. Women of reproductive age with a history of using intrauterine devices are 2.28 times more likely to experience an ectopic pregnancy than women of reproductive age who do not use intrauterine devices $(\mathrm{aOR}=$ 2.28; $95 \% \mathrm{CI}=1.74$ to $2.98 ; \mathrm{p}<0.001$ ).

\section{b. Funnel plot}

The results of the analysis in Figure 5 show that there is a publication bias indicated by the asymmetric distribution of the right and left plots and does not form an inverted funnel. There is one study on the left that has a standard error of $>0.6$.

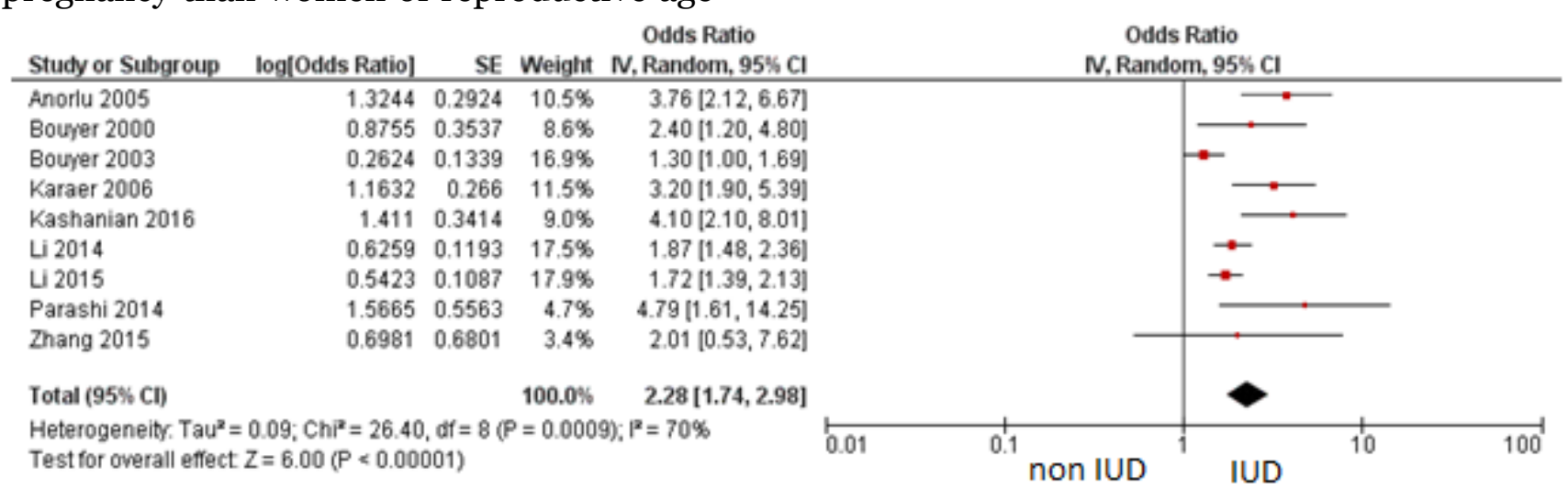

Figure 4. Forest plot The relationship between history of using intrauterine devices and the incidence of ectopic pregnancy

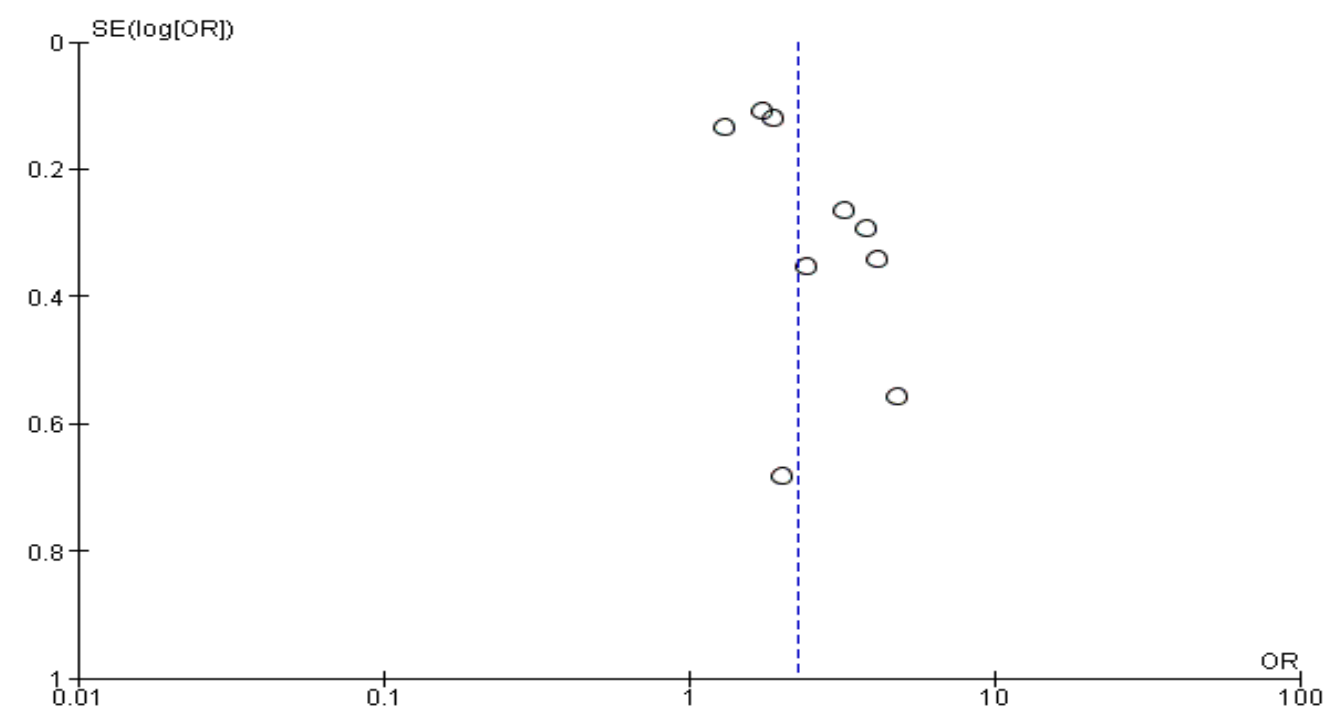

Figure 5. Forest plot The relationship between history of using intrauterine devices and the incidence of ectopic pregnancy

\section{DISCUSSION}

Research related to the relationship of smoking and history of using intrauterine contraception to the incidence of ectopic pregnancy is spread across 3 continents, namely Asia, Africa and Europe which is divided into 2 intervention categories, namely smoking as many as 7 articles from 
France, Turkey, Germany, Iran, Cameroon and history of smoking. 9 articles were cinducted in France, Nigeria, Turkey, Iran, and China.

Based on the primary research, found the basic similarities of the research, including the research subjects are women of reproductive age, the intervention given is smoking with a comparison of not smoking. However, there are also fundamental differences in the primary studies taken, including the smallest number of samples used as many as 250 and the largest as many as 2486 and the average age of women 18-43 years in the relationship between smoking and the incidence of ectopic pregnancy. While the relationship between history of using intrauterine devices and the incidence of ectopic pregnancy, the smallest sample size is 380 and the largest is 4830 with an average age of 15-45 years. Women who are active smokers and 2 articles are women who are active smokers with the number of cigarettes consumed more than 20 cigarettes per day. The primary study of 9 articles regarding the history of using intrauterine devices did not explain the duration and type of use of intrauterine devices.

Based on the results of the analysis of 7 articles regarding smoking on the incidence of ectopic pregnancy, it was reported that there was high heterogeneity between trials $\left(\mathrm{I}^{2}=78 \%\right.$; $\left.\mathrm{p}=0.002\right)$, so the Random Effect Model (REM) was used. Based on the results of the analysis from the primary research, this high heterogeneity occurs due to variation or diversity between populations, which is seen from the different number of samples between the case group and the control group, the age of women who tend to vary between studies.

Based on the results of the forest plot of 7 research articles on smoking on the incidence of ectopic pregnancy, it was also found that women of reproductive age who smoked had a 2.20 times risk of having an ectopic pregnancy compared to women of reproductive age who did not smoke $(\mathrm{aOR}=$ 2.20; $95 \% \mathrm{CI}=1.45$ to $3.34 ; \mathrm{p}=0.002$ ).

The results of this study are supported by research conducted by Karaer et al. (2006), suggested that women with smoking had a 1.70 times risk of having an ectopic pregnancy compared to women who did not smoke and the results were statistically significant $(\mathrm{aOR}=1.70 ; 95 \%$ $\mathrm{CI}=1.10-2.63 ; \mathrm{p}=0.01)$. Smoking as a risk factor for ectopic pregnancy. Smoking can reduce tubal motility and nicotine has an adverse effect on ciliary movement. Nicotine has also been shown to delay the entry of the egg into the uterus and the formation and implantation of a blastocyst. In addition, smoking can reduce humoral and cellular immunity.

In line with these studies, Karaer et al. (2013), suggested that women who smoked had a 1.76 times risk of having an ectopic pregnancy compared to women who did not smoke but it was not statistically significant $(\mathrm{aOR}=1.76 ; 95 \% \mathrm{CI}=0.89-3.48 ; \mathrm{p}=0.104)$. The research of Kashanian et al. (2016), also stated that women who smoked had a 5.70 times risk of having an ectopic pregnancy compared to women who did not smoke and the results were statistically significant $(\mathrm{aOR}=5.70 ; 95 \% \mathrm{CI}=2.80$ to 11.60 ; $\mathrm{p}<0.001)$. Smoking is considered a risk factor for ectopic pregnancy. This suggests a causative effect of tobacco on the fallopian tubes.

Mindjah et al. (2018), stated that women who smoked had a 2.68 times risk of having an ectopic pregnancy compared to women who did not smoke and the results were statistically significant (aOR = 2.68; 95\% CI= 1.12 to $6.41 ; \mathrm{p}=0.026)$. Cotinine (an abundant nicotine metabolite) from cigarettes increases the expression of 
prokineticin receptor-1 (PROKR1), a regulator of smooth muscle contractility and a gene important for implantation in the fallopian tube. In this regard, they hypothesized that smoking causes women to have an ectopic pregnancy by altering tubal PROKRI expression resulting in altered fallopian tube function. In the research of Taran et al. (2015), stated that smoking has been shown to be a risk factor for increasing ectopic pregnancy. On the basis of laboratory studies in humans and animals, the researchers controlled for several mechanisms by which smoking might play a role in ectopic pregnancy. These mechanisms include delayed ovulation, altered tubal and uterine motility, or altered immunity.

Research conducted by Bouyer et al. (2000), women who smoked were 1.10 times more likely to have an ectopic pregnancy than women who did not smoke but it was not statistically significant $(\mathrm{aOR}=$ $1.10 ; 95 \% \mathrm{CI}=0.60$ to $2.02 ; \mathrm{p}=0.47)$. Bouyer et al. (2003), also stated that women who smoked had a 3.90 times risk of having an ectopic pregnancy compared to women who did not smoke and the results were statistically significant $(\mathrm{aOR}=$ $3.90 ; 95 \% \mathrm{CI}=2.60$ to $5.85 ; \mathrm{p}<0.001$ ). This shows that there is a dose-effect relationship between tobacco use when smoking more than 20 cigarettes per day which can play a role in various stages of reproduction: ovulation, fertilization, viability, and implantation.

Based on the analysis of 9 articles regarding the history of using intrauterine contraception on the incidence of ectopic pregnancy, it was reported that there was high heterogeneity between trials (I2=70\%; $\mathrm{p}=0.009)$, so the Random Effect Model (REM) was used. Based on the results of the analysis from the primary research, this high heterogeneity occurs due to variation or diversity between populations, which is seen from the different number of samples between the case group and the control group, the age of women who tend to vary between studies.

Based on the results of the forest plot of 9 research articles regarding the history of using intrauterine devices on the incidence of ectopic pregnancy, it was also found that women of reproductive age with a history of using intrauterine devices are at risk of 2.28 times experiencing the incidence of ectopic pregnancy compared to women of reproductive age who do not use contraceptives intrauterine device $(\mathrm{aOR}=$ 2.28; $95 \% \mathrm{CI}=1.74$ to $2.98 ; \mathrm{p}<0.001$ ).

The results of this study are supported by research by Anorlu et al. (2005) aimed to identify risk factors for ectopic pregnancy in women of reproductive age in Nigeria. In this study, it was shown that women who had a history of using intrauterine devices had a 3.76 times risk of having an ectopic pregnancy compared to women who did not use intrauterine devices $(\mathrm{aOR}=3.76 ; 95 \% \mathrm{CI}=2.12$ to 6.67$)$. Another study by Bouyer et al. (2000), said that women of reproductive age with a history of using intrauterine devices had a 2.40 times risk of having an ectopic pregnancy compared to those who did not use intrauterine devices and the results were statistically significant $(\mathrm{aOR}=2.40 ; 95 \%$ $\mathrm{CI}=1.20$ to $4.80 ; \mathrm{p}=0.02)$. The risk of insertion of a contraceptive device in the uterus occurs because intrauterine inflamemation increases over time due to the presence of a foreign body IUD which results in a decrease in the number of intrauterine pregnancies to the number of ectopic pregnancies.

A similar study on the risk of ectopic pregnancy and history of using intrauterine devices was conducted by Bouyer et al. (2003), stated that women of reproductive 
age with a history of using intrauterine devices had a 1.30 times risk of having an ectopic pregnancy compared to those who did not use intrauterine devices but this was not statistically significant $(\mathrm{aOR}=1.30$; $95 \% \mathrm{CI}=1.00$ to $1.69 ; \mathrm{p}=0.10$ ). History of intrauterine contraceptive use has an etiologic role in ectopic pregnancy itself. Karaer et al. (2006), stated that women with a history of using intrauterine devices had a 3.20 times risk of having an ectopic pregnancy compared to those who did not use intrauterine devices and the results were statistically significant $(\mathrm{aOR}=3.20 ; 95 \%$ $\mathrm{CI}=1.9$ to $5.39 ; \mathrm{p}<0.001)$. Intrauterine devices do not prevent ovulation and are more effective at preventing intrauterine pregnancy than extrauterine pregnancy. This accounts for most of the higher risk of ectopic pregnancy for intrauterine device users when compared to non-users.

Kashanian et al. (2016), stated that women of reproductive age with a history of using intrauterine devices had a 4.10 times risk of experiencing an ectopic pregnancy compared to those who did not use intrauterine devices and the results were statistically significant $(\mathrm{aOR}=4.10 ; 95 \% \mathrm{CI}=$ 2.10-8.01; $\mathrm{p}=0.01$ ). Li et al. (2014), also stated that women of reproductive age with a history of using intrauterine devices had a 1.87 times risk of having an ectopic pregnancy compared to those who did not use intrauterine devices $(\mathrm{aOR}=1.87 ; 95 \% \mathrm{CI}=$ 1.48 to 2.36). The mechanism of action of the IUD can cause changes in the endometrium, leukocyte infiltration into the uterus, and the accumulation of macrophages thought to cause extrauterine pregnancy when ovulation occurs.

Research by Li et al. (2015), said that women of reproductive age with a history of using intrauterine devices had a 1.72 times risk of experiencing an ectopic pregnancy compared to those who did not use intra- uterine devices and the results were statistically significant $(\mathrm{aOR}=1.72 ; 95 \% \mathrm{CI}=1.39$ to $2.13 ; \mathrm{p}=0.001$ ). Although the exact mechanism of implantation occurring outside the uterus is not well understood, it is thought that IUD-induced inflammation may occur in endosalpinx deciliation and subsequently delay egg transport, leading to an ectopic pregnancy. In line with these studies, Zhang et al. (2015), in his study stated that a history of using contraceptive devices in utero also increased the risk of ectopic pregnancy $(\mathrm{aOR}=2.01 ; 95 \% \mathrm{CI}=$ 0.53 to 7.62 ).

In one of the primary studies with a case control study design, Parashi et al. (2014), showed that the CI range is very wide (1.61 to 14.25). This can be caused by missing data in the follow-up process. This missing or missing data is probably data in the group exposed to positive risk factors so this can lead to a wide range of CIs. While other causes may be due to the small number of samples.

Based on the results of the analysis of 7 articles regarding smoking on the incidence of ectopic pregnancy, the funnel plot showed no publication bias as indicated by the symmetrical distribution of the right and left plots where there were 3 plots on the right and 4 plots on the left. The plot on the left of the graph has a standard error of 0.1 and 0.4 between, while the plot on the right of the graph has a standard error between 0.2 and 0.5 . Meanwhile, the results of the analysis of 9 articles regarding the history of using intrauterine devices against publications indicate that there are publications indicated by the asymmetric distribution of the right and left plots. There is one study on the left that has a standard error of >0.6. The possibility of publication bias is presented by a funnel plot that shows the relationship between the effect size of the study and the sample 
size of the various studies studied, which can be measured in different ways (Murti, 2014).

The advantage of this meta-analysis is that it can control for confounding factors. There are several confounding factors that are important to be controlled by researchers such as history of tubal surgery, history of abortion, history of infertility. This is important because the effect of these confounding factors does not increase or decrease the true relationship between smoking and history of using intrauterine devices with ectopic pregnancy. Therefore, the researcher used the adjusted odds ratio relationship measure with multivariate analysis because it had controlled for confounding factors so that the actual results were obtained between the effects of exposure and also the outcome, namely between smoking and history of using IUD to ectopic pregnancy.

\section{AUTHOR CONTRIBUTION}

Ridha Rossela Yanuari is the main researcher who chooses the topic, conducts a search for data collection in this study. Eti Poncorini Pamungkasari and Vitri Widyaningsih conducted data analysis and review of research documents.

\section{FUNDING AND SPONSORSHIP}

This study is self-funded.

\section{CONFLICT OF INTEREST}

There is no conflict of interest in this study.

\section{ACKNOWLEDGMENT}

The researcher would like to thank all those who have helped in the preparation of this article and also thank the database providers PubMed, Google Scholar, and ScienceDirect.

\section{REFERENCES}

Anorlu RI, Oluwole Abudu OO, Adebajo S (2005). Risk factors for ectopic pregnancy in Lagos, Nigeria. Acta Obstet Gynecol Scand, 84(2): 184-188. https://doi.org/10.1111/j.0oo1-6349.2005.00684.x

Bouyer J, Rachou E, Germain E, Pouly J, Fernandez H, Coste J, Pouly J (2000). Risk factors for extrauterine pregnancy in women using an intrauterine device. Fertility And Sterility.74(5), 899-908. https://doi.org/10.1016/So015-0282(00)01605-8

Bouyer J, Coste J, Shojaei T, Pouly J, Fernandez H, Gerbaud L, Job-Spira N (2003). Risk factors for ectopic pregnancy: a comprehensive analysis based on a large case-control, population-based study in France. Am J Epidemiol. 185(94): 185-194. https://doi.org/10.1093/aje/kwf190.

CEBMa (2014). Critical Appraisal for Case Control Study. Amsterdam.

Demirdag E, Guler I, Abay S, Erdem M, Erdem A (2016). The impact of expectant management, systemic methotrexate and surgery on subsequent pregnancy outcomes in tubal ectopic pregnancy. Ir J Med Sci. 186(2): 387-392. https://doi.org/10.1007/s11845-0161419-5.

Karaer A, Avsar FA, Batioglu S (2006). Risk factors for ectopic pregnancy: a casecontrol study. Aust N Z J Obstet Gynaecol. 46(6), 521-527. https://doi.org/10.1111/j.1479-828X.2006.o0653.x

Kashanian M, Baradaran HR, Mousavi SS, Sheikhansari N, Bararpour F (2016). Risk factors in ectopic pregnancy and differences between adults and adolescents is consanguinity important. J Obstet Gynaecol. 36(7): 935939. https://doi.org/10.1080/01443- 
Yanuari et al./ Smoking, Intrauterine Device Uptake, and Ectopic Pregnancy

615.2016.1174828

Lewis SL, Bucher L, Heitkemper MM, Harding MM, Kwong L, Roberts D (2017). Medical-Surgical Nursing: Assesment of Management of Clinical Problems (5th ed.). Elsevier Mosby.

Li C, Zhao W, Meng C, Cao S, Ping H, Qin G, Cao S, Xi X, Zhu Q, Li X, Zhang J (2014). Contraceptive Use and the Risk of Ectopic Pregnancy: A MultiCenter Case Control Study. Plos One, 9(12). https://doi.org/10.1371/journal.pone.0115031

Li C, Zhao W, Zhu Q, Cao S, Ping H, Xi X, Qin G, Yan M, Zhang D, Qiu J, Zhang $\mathrm{J}$ (2015). Risk factors for ectopic pregnancy: a multi- center case-control study. BMC Pregnancy Childbirth, 19. https://doi.org/10.1186/s12884015-0613-1

Mindjah YAA, Essiben F, Foumane P, Dohbit JS, Mboudou ET (2018). Risk factors for ectopic pregnancy in a population of Cameroonian women. PlosOne,13(12).https://doi.org/10.137 1/journal.pone.0207699
Moini A, Hosseini R, Jahangiri N, Shiva M, Akhoond MR (2014). Risk factors for ectopic pregnancy: A case - control study. J Res Med Sci, 19(9), 844-849.

Murti B (2018). Prinsip dan Metode Riset Epidemiologi. Surakarta: Universitas Sebelas Maret.

Orazulike NC, Konje JC (2013). Diagnosis and management of ectopic pregnancy. BMC Women's Health, 9(4), 373-385.

Parashi S, Moukhah S, Ashrafi M (2014). Main Risk Factors for Ectopic Pregnancy: A Case-Control Study in A Sample of Iranian Women. Int J Fertil Steril, 8(2), 147-154.

Patil M (2012). Ectopic pregnancy after infertility treatment. J Hum Reprod Sci, 5(2): 154-165. https://doi.org/10.4103/0974-1208.101011

Sivalingam VN, Duncan WC, Kirk E, Shephard LA, Horne AW (2011). Diagnosis and management of ectopic pregnancy. J Fam Plann Reprod Health Care, 37(4): 231-240. https://doi.org/10.1136/jfprhc-2011-007. 